\title{
\begin{tabular}{ll}
\hline 著 \\
\hline
\end{tabular} \\ 慢性病患者の療養のあり様に関する研究

\begin{tabular}{|c|c|c|c|}
\hline 木 & 恵*1・兼 & 百合子*1・小 & 野 \\
\hline 雨 & 子*3 ・井 & 俊 子*4 - 平 & 野 \\
\hline 原 & 子*5 • 志自岐 & 子*5 • 中 & 西 \\
\hline
\end{tabular}

\section{The Qualitative Analysis of Self Care Attitude toward Chronic Illness}

\author{
Harue Masaki*1 • Yuriko Kanematsu*1 - Tsuruko Ono*2 • \\ Etsuko Amemiya*3 - Toshiko Ibe*4 $•$ Kayoko Hirano*5 • \\ Itsuko Ishihara*5 $\bullet$ Yasuko Shijiki*5 $\bullet$ Mutsuko Nakanishi*5 \\ ${ }^{*}$ School of Nursing, Chiba University \\ *2 College of Medical Technology, Okayama University \\ ${ }^{*} 3$ Kanagawa Prefectual Junior College of Nursing and Medical Technology \\ *4 St. Lukes College of Nursing, \\ *5 The Japanese Red Cross College of Nursing
}

\begin{abstract}
This paper presents the qualitative data of a series of our study "A Study of Structure of Patient Self Care with Chronic Illness and Role of Nursing”.

This study is aimed to explore the various kinds of self care attitude toward chronic illness. Interviews with 152 adult outpatients with one of the selected four chronic illness provide the major source of data.

The findings indicate seven styles of self care attitude toward chronic illness. These are; perfectionist, actual life, natural life, low selfesteem, dependent on others, shouldering burden, defiant. These findings suggest that patients need diffrent focus of nursing care according to the styles found in this study.
\end{abstract}

\section{要 旨}

「慢性病患者のセルフケアの構造と看護の役割に関する研究」と題して行った一連の研 究の中で, 本研究は質的分析を中心とする面接調査の結果を検討したものである. 本研究 は, 患者の療養生活に関する自由な表現から, 慢性病患者の様々な療養のあり様を捉える ことを目的とした。

慢性病を有する外来通院患者 152 名を対象とし, 患者の療養のやり方の特徵を検討した

$* 1$ 千葉大学看護学部 $* 2$ 岡山大学医療技術短期大学部 $* 3$ 神奈川県立衛生短期大学 $* 4$ 聖路加看護大学

*5 日本赤十字看護大学＼cjkstart受理：平成 4 年 6 月 10日 Accepted：June 10, 1992 
結果， 7 つのタプの療養のやり方が見いだされた。すなわち, 完全主義型, 現実型, 自 然態型, 自己価值低下型, 依存型, 重荷型, 反抗型である. この患者の療養のあり様の特 徵に応じて, 看護の課題が異なることが示唆された。

\section{〔はじめに】}

我々は「慢性病患者のセルフケアの構造と看 護の役割に関する研究」と題して一連の研究 1 7) を行った．その中で本研究は，質的分析を中心 とする面接調査の結果を検討したものである. 面接調査では, 慢性病患者が療養生活を送る上 で日々, 行い, 感じ, 考㝋ていることなど患者 の自由な表現から, 慢性病患者の様々な療養の あり様を捉えることを目的とした，その結果を 踏まえ, 慢性病患者看護について考察したい。

\section{I . 方 法}

1 ）面接調査の内容と方法

面接調査の内容は, 慢性病患者のセルフケア の中でも特に病状のコントロールに必要な行動 を療養と捉え, 療養の実際のやり方とそれに影 響すると考光られる家族や周囲の協力や本人の 信条などについて項目を設定した. 設定項目と しては, 実際の療養のやり方(食事, 服薬, 運 動, 労働, 規則正しい生活, その他について), 療養行動 (食事や活動) の目安, 家族の協力, 周 囲の人に病気であることを知らせているか，慢 性病に罹患した生活の以前の生活と比べてのプ ラス面，拈よび，療養を続けていく上でのモッ トーである。

面接は半構成式面接法とし, 設定項目にかか わらず患者の自由な発言を聞き取った，予備調 査ではテープ録音による逐語記録を資料とした が，本調査では面接者の面接記録を資料として 用いることとしたため，面接者のコメント欄を 新たに設け，資料となる記録の充実を図った。 コメントの内容は, 患者の行っているセルフケ 了の適切さ・主体性・困難や苦痛の程度, 目安 の適切さ, セルフケアに影響する環境, 療養行 動と他の生活との優先性, 目立った観察事項, 患者がこの面接中に語りたかったことの要約, についての面接者の判断や感想である.
面接は，患者の外来受診時に筆者らが一対一 で約 $1 \sim 2$ 時間行った．面接記録は，面接をし ながら面接者がその場で患者の言動をなるべく そのまま記録し，面接終了後に面接者のコメン トを記入した。

2 ) 対象は, 年齢18歳以上で, 慢性疾患の診断 成立後六力月以上経過している男女. 疾患とし ては, 糖尿病 ( I 型を除く), 心疾患・高血圧, 慢性腎炎・慢性腎不全 (透析患者・CAPD患者 を含む), 慢性肝炎. 本調査の質問紙調査(別報 7)它実施し，面接調査に応諾した患者である. 面接調査を実施した156名のうち面接資料内容 不足のもの 4 名を除く152名を対象とした.

3) 分析方法

面接者の面接記録を分析資料として用い，予 備調査 ${ }^{4)}$ の結果得られた療養の各タイプに対象 を分類し，それぞれの療養のあり方の特徵につ いて検討する.

予備調査に括ける療養のタイプ分けに拉いて は, 実際の療養のやり方関する患者の表現か ら, 療養行動の主体性, 療養生活への専心度を 評価し, 分類した。 その結果, 患者本人から療 養生活の実際について具体的な方法が表現され， 患者は主体的に療養に専念していると評価でさ た『自分で取り組む療養生活』, 療養の中心課 題である食事療法を全面的に食事作りにあたる 妻にまかせ, 患者自身は主体的に取り組んでい ないと評価できた『妻まかせの療養生活』，お よび，療養の実際について質問しているにもか かわらず，不安な気持ちや心配事を表現し，そ れらのために自分の療養に汪とんど専念できて いないと評価できた『専念できない療養生活』 に大別できた。 また，『自分で取り組む療養生 活』は, 療養行動に伴う苦労感の表現形態の違 いでさらに 4 つに分けられた。すなわち，厳し く細かく自分に療養を課しているタイプI（完 全主義型)，苦労を表現するが自分なりに工夫 して療養しているタイプII (現実型), 苦労をあ 
まり表現せず無理のない療養を送っているタイ プIII (自然態型), 守れない部分ばかり多く語る タイプ IV (自己価值低下型)である。『妻まかせ の療養生活』をタイプ V(依存型), 『専念でき ない療養生活』をタイプVI(重荷型)とした。

\section{II. 結 果}

\section{1. 療養のタイプの分類と対象の背景}

対象を予備調査で得られた療養の各タイプで 分類したところ, タイプI, II, III, IV, V, VIは，それぞれ，5名，82名，51名，6名，2 名, 3 名であり, タイプII とIIIが $87.5 \%$ と大半 で, タイプ I, $\mathrm{N}, \mathrm{V}, \mathrm{VI}$ 極少数であった。 タイプ I 〜VIに分類できなかった 3 名は，自分 の不適切な療養行動, あるいは医師の指示に従っ ていないことを平気で述べていることが特徵的 であり,タイプVII 新たに分類でき，反抗型と 命名した.

各タイプの対象の背景を表 1 に示した。年齢 は, タイプIII, V, VIで高く, 特に多いタイプ II と IIIで平均年齢を比較すると, 有意に $(\mathrm{t}$ 検 定)タイプIIIがIIより高かった。性別で比較す ると，タイプIII男性に，タイプ VVとVIは女性 に多かった。疾患別では, 糖尿病と腎臓病は夕 イプIIに，肝㵴病はタイプIIIに多かった。コン トロール度では，タイブIIに不良の者が多い。

就業形態は患者が自分で時間を調整しやすいか ぞうかを中心に分類したが，それでは，タイプ
II 常勤者, 主婦, タイプIIIに自営業, 無職の 割合が高かった，罹患期間は，平均の比較では タイプII とIIIで特に差はみられなかった。

\section{2. 療養の各タイプの特徴}

タイプ I は, 療養生活の実際についてかなり 詳しく述べており, 述べられている内容も具体 的で細かく，その療養行動を徹底して行ってい る様子を表現している。モットーの表現として 「がまんに耐えること」(気力がもてるように 自分で(生活を)つくりあげる，自分が負けたら それで終わりだから」「必ず何かやることをそ ばに掠いておく」などがみられるよらに，厳し い自己コントロールを自分に課していた。この タイプに属する 5 名のらち 1 名は, 最近血糖コ ントロールが不良になってきたことから「こん なに工夫して一生懸命やっているのに，これ以 上何を気をつけたらいいんでしょう，これだけ 神経を使っていてどうして下らないんでしょう」 と述べて括り，自分を厳しく制して療養を行っ ているにもかかわらず, 病状のコントロールが らまくいかないもどかしさや苛立ちを表現して いた.

タイプIIは, 実際の療養のやり方の面で困難 感を述べているもので, 困難の内容としては, 「制限しなくてはならないことをよく分かって いるが，つい食べたり飲んだりしてしまら」が 多く, また，家庭や社会生活と療養生活を両立

\section{表 1 療養の各タイプ別対象の背景}

\begin{tabular}{|c|c|c|c|c|c|c|c|c|c|c|c|c|c|c|c|c|c|c|}
\hline & 性別(人) & \multirow{2}{*}{$\begin{array}{l}\text { 年齢 (歳) } \\
\text { 平均土SD }\end{array}$} & \multicolumn{4}{|c|}{ 病 名 (人) } & \multicolumn{4}{|c|}{ コントロール度 (人) } & \multicolumn{7}{|c|}{ 就業形態(人) } & \multirow{2}{*}{$\begin{array}{c}\text { 罹病期間 (年) } \\
\text { 平均 } \pm \mathrm{SD}\end{array}$} \\
\hline タイプ & 男 女 & & 糖 心 & 肝 & 腎 1 & NAC & Good & Fair & Poor & NA & 常 & 1ㅇ & 自 & 無 & 主 & & $\mathrm{NA}$ & \\
\hline I & 3 & $60.6 \pm 11.3$ & 2 & 2 & 0 & 0 & 2 & 2 & 0 & 1 & & 0 & 0 & 1 & 1 & 0 & 0 & $11.8 \pm 9.0$ \\
\hline II & 5230 & $58.8 \pm 10.9$ & 3132 & 10 & 8 & 1 & 35 & 27 & 17 & 3 & 24 & 1 & 7 & 16 & 20 & 8 & 6 & $8.7 \pm 8.1$ \\
\hline III & 3813 & $63.6 \pm 11.5$ & 1219 & 19 & 1 & 0 & 26 & 21 & 4 & 0 & 16 & 2 & 6 & 12 & 8 & 1 & 6 & $9.4 \pm 8.9$ \\
\hline IV & 1 & $56.2 \pm 8.4$ & 0 & 1 & 2 & 0 & 2 & 3 & 1 & 0 & 0 & 1 & 0 & 2 & 3 & 0 & 0 & $6.8 \pm 7.8$ \\
\hline $\mathrm{V}$ & 1 & $72.0 \pm 0.0$ & 0 & 0 & 0 & 0 & 1 & 1 & 0 & 0 & & 0 & 1 & 1 & 0 & 0 & 0 & $5.0 \pm 1.0$ \\
\hline VI & 0 & $64.7 \pm 7.9$ & 0 & 3 & 0 & 0 & 3 & 0 & 0 & 0 & 0 & 0 & 0 & 0 & 2 & 1 & 0 & $15.0 \pm 12.2$ \\
\hline VII & 2 & $59.0 \pm 7.5$ & 1 & 1 & 0 & 0 & 1 & 2 & 0 & 0 & 1 & 0 & 1 & 1 & 0 & 0 & 0 & $10.3 \pm 8.5$ \\
\hline
\end{tabular}

病 名

糖：糖尿病心：心疾患・高血圧 肝：肝臓病 就業形態

常：常勤パ:パート自：自営無：無職主：主婦他：その他 
できないことがあげられている。療養をしてい かなければといら気持ちはあるため, 種々の工 夫が行われているが，その中には積極的に解決 していこうとしているものから，妥協してあき らめている場合もある。 また，解決することが 困難で負担感の大きい人もいる，慢性病をもっ た生活の以前の生活と比べてのプラス面につい ては，「健康を気づからようになった」「人生や 自分を見つめ直せた」「家族や周囲のありがた さに気付いた」「病者への理解が深まった」が あげられて招り，一方「プラス面はない」や 「マイナスが多い」と述べる者もいた。モットー については, 「仕事や趣味の達成や実行」「自分 の身体は自分で守る」「自分に合った生活を作 る」「充実した人生」「世の中に役立つように」 があげられていた。

タイプIIIは, 困難感なく無理のない療養生活 を行っている者で，その中には，療養上の制限
があまりなく自由にやっている者，無理をしな いように生活をある程度縮小している者, 療養 がすでに習慣化している者などがいた。プラス 面は，「自分の身体に関心を払うことの意義が わかった」「趣味・関心の対象が変わった」な どがあり，一方「プラス面はない」や「そんな こと考えたこともない」と述べる者もいたモモッ トーについては，「自然態で生活」「自分のこと は自分で」「自分の体を基調にした生活」「中庸 な生活」「神仏の加護」などが述べられていた。

タイプ $\mathrm{V} は$, 療養行動について守れない部分 を多く述べる者で, 発病後の自分に対して自己 価値の低下の感情や意欲の減退, 社会的孤立感, 不安が述べられていた。プラス面の表現は 6 名 中 5 名が「ない」と答光ており，モットーにつ いての表現も慢性病が大きな気持ちの負担になっ ていることをしめしていた.

タイプ V は，家族に自分の療養上必要なこと

表 2 困難感なしの理由

\begin{tabular}{|c|c|}
\hline 分 & 表 \\
\hline $\begin{array}{l}\text { (a) 医師より指示されて } \\
\text { いる療養上の生活制 } \\
\text { 限が少ない }\end{array}$ & $\begin{array}{l}\text { ・薬を飲んでいれば何をしてもよいと言われた. 別に食事療法はやっていない } \\
\text { ・外来に来ていればよいと，特に医師から生活上の注意点は言われていない }\end{array}$ \\
\hline $\begin{array}{l}\text { (b) 遵守しなければとい } \\
\text { う意識が少ない }\end{array}$ & 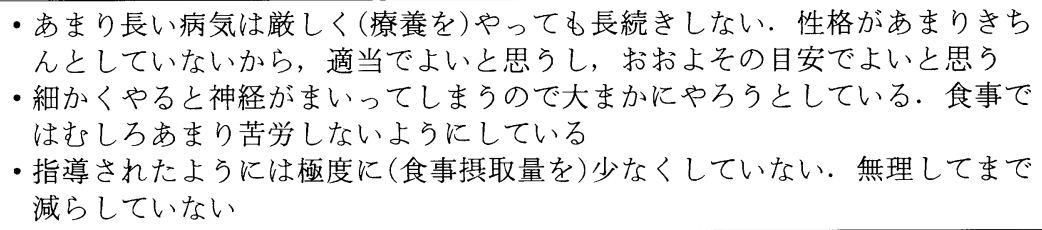 \\
\hline $\begin{array}{c}\text { (c) 生活を縮小して, 療 } \\
\text { 養に専念している }\end{array}$ & $\begin{array}{l}\text { ・つきあいをしなくなった } \\
\text { ・仕事を辞めた，役をおりた } \\
\text { ・入院中に出てきた食事( } 2 \text { 月分)を記録し，それを年がら年中食べている } \\
\text { ・守りの体制に生き方を変えた }\end{array}$ \\
\hline $\begin{array}{l}\text { (d) 療養生活と競合する } \\
\text { 生活内容の割合や度 } \\
\text { 合いが小さい }\end{array}$ & ・現役を引退し，のんびりやれている \\
\hline $\begin{array}{l}\text { (e ) 周囲の理解や協力あ } \\
\text { り }\end{array}$ & $\begin{array}{l}\text { ・減塩しょうゆ使用. 家族皆私に(味付けを)合わせた } \\
\text { •女看か護婦みたいなもので, うるさいくらい. 妻も一緒の食事をしている } \\
\text { ・上司, 同僚皆私が病気であることを知っているので, 配慮してくれる }\end{array}$ \\
\hline $\begin{array}{l}\text { (f) 療養行動が習慣化し } \\
\text { ている }\end{array}$ & 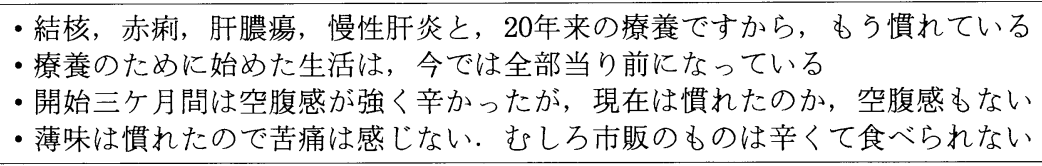 \\
\hline （g）達観 & $\begin{array}{l}\text { ・自分を知ってセーブしない人の世話になることが多くなる. 内臓の働さが低 } \\
\text { 下している事や, 年齢や体力に沿ったものの考え方を持った方がいい } \\
\text { ・人間は習慣性のあるる動物だから, 自分がこうすると決めて行っていれば，そ } \\
\text { れが自の○になって，その範囲で無理なく暮らせる }\end{array}$ \\
\hline
\end{tabular}


を全面的に依存している者で，一人は妻に，一 人は娘に任せて拈り，面接中も同席した妻が注 とんど代弁して，患者自身は自分の意見をほ之 んど語らなかった。

タイプVIは，自分の療養に専念できない状況 にある者で, 一人は心蔵病の夫の世話で自分の 療養がままならぬ状態であり, 残りの 2 人は面 接中の話題が汇とんぞ他の関心事(自分の膝の 痛み, 夫の死のショック)であった.

タイプVIIは, 不適切な療養行動を平気で述べ ている者で, 自分の不適切な療養行動を正当化 しており, また, 療養の必要性の理解が之しい 者だった。

\section{3. 療養上の困難感有無の理由}

「自分で取り組む療養生活」に分類されるタ
イプ I 〜 IVは，困難感の表現形態で分類したタ イプである.タイプI, II, IVの患者の言動か ら困難感ありの理由を, タイプIIIの患者の言動 から困難感なしの理由を抽出した。困難感なし の理由を表 2 亿, 困難感ありの理由を表 3 亿示 した.

\section{III. 考 察}

\section{1. 療養の各タイプにみられた特徴}

慢性病之共に生きる患者の課題はストラウス ${ }^{8}$ が述べているよらに療養行動の実行のみではな い. 症状の管理をはじめとして, 病気の過程に 生じる変化への適応, 生活の常態化, 社会的疎 外の予防・我慢, 財源や家族的な問題など患者 の課題は多く，それらの課題との関連の中で療 養生活が成り立っている. 本結果で得られた療

\section{表 3 困難感ありの理由}

\begin{tabular}{|c|c|}
\hline 分 & の \\
\hline 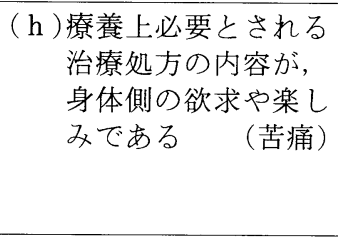 & 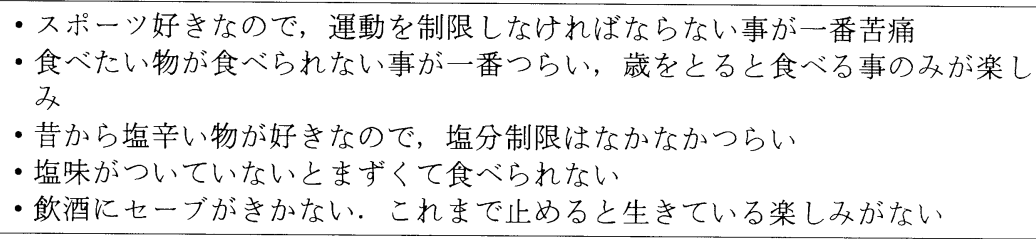 \\
\hline $\begin{array}{l}\text { ( i ) 療養行動と競合する } \\
\text { 生活内容の割合や度 } \\
\text { 合が大きい } \\
\text { (苦労・負担) }\end{array}$ & $\begin{array}{l}\text { ・仕事が三交替制なので，一律にはいかず，難しい } \\
\text { ・仕事上，体調不良で早く㷌りたい時も帰れない時がある } \\
\text { ・地方公演が多く，それに伴い食事が乱れる }\end{array}$ \\
\hline $\begin{array}{l}\text { ( } \mathrm{j}) \text { 自分の療養のこと以 } \\
\text { 外に優先させなけれ } \\
\text { ばならないことがあ } \\
\text { る (苦労・負担) }\end{array}$ & 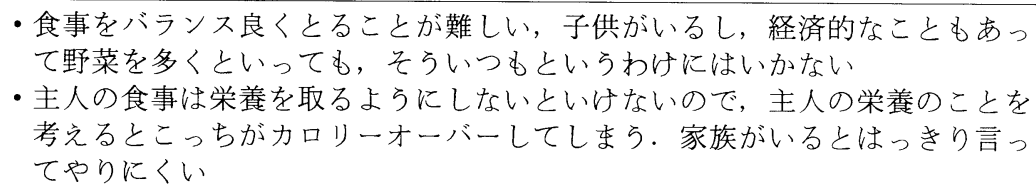 \\
\hline $\begin{array}{c}\text { (k) 自分が慢性病である } \\
\text { ことを隠し通す } \\
\text { (苦労・負担) }\end{array}$ & $\begin{array}{l}\text { ・家族以外には自分が病気のことを誰にも知らせていないので, 無理をする时 } \\
\text { もあり, 精神的にきつい } \\
\text { ・仕事仲間との会合で無理につきあったりする }\end{array}$ \\
\hline $\begin{array}{l}\text { (1) 周囲の理解や協力が } \\
\text { 得られない } \\
\text { (苦労・負担) }\end{array}$ & $\begin{array}{l}\text { ・女房が食事療法を理解してくれない，単位計算表を壁に貼ると，女房はそん } \\
\text { なの貼る必要ないと言う } \\
\text { ・相談できる人がいない } \\
\text { ・家族に「トイレが薬臭い」と言われ，申し訳ないと思っている }\end{array}$ \\
\hline （m）面倒 & $\begin{array}{l}\text { ・食事療法は面倒 } \\
\text { ・歩くのが外食のメニュー選びが大変 }\end{array}$ \\
\hline $\begin{array}{l}\text { (n) 遵守しなければとい } \\
\text { う意識が強いが，コ } \\
\text { ントロールがうまく } \\
\text { いかない (負担) }\end{array}$ & $\begin{array}{l}\text { ・百主人と二人で食事だけのことにかけている毎日.これだけやってもコン } \\
\text { トロールが良くならない } \\
\text { ・つい食べてしまう }\end{array}$ \\
\hline
\end{tabular}


養のタイプは，それぞれの患者が慢性病の療養 を自分の生活の中にある程度持続可能な方法と して組み入れた，自分なりの療養の仕方の多様 性を示していると考えられる. 各タイプの割合 をみると、タイプII (現実型) と III (自然態型)が 八割以上であったことから, 療養のタイプはII とIIIのような療養のやり方が標準的な型で, タ イプ I (完全主義型), タイプ IV (自己価值低下 型), タイプV(依存型), タイプ VI (重荷型), タイプVII (反抗型)はまれにしか存在しない型で あると思われる。

タイプIIが最も多く，一般的なタイプだった. 慢性病の療養生活は日常生活や社会生活の上で 成ち立ち，それらの生活と両立させていかなけ ればならないといら点で, 何らかの困難が生じ るのは当然のことと考兄られる，その中で患者 それぞれが自分なりに適応しようとして種々工 夫がなされていく，それに対してタイプIIIは，

苦労をあまり感じておらず無理のない療養がで きているタイプだった。このタイプIIIの人も多 かったが，では何故，日常生活・社会生活に療 養生活を組み込んでいく上で，この人達には葛 藤や困難感など摩擦を生じないで済んでいるの だろらか。

タイプII とIIIの相違点をみてみると，タイプ IIIはIIより年齢が高かった. 年齢が高いという ことは，退職や子育ての終了などにより環境か ら生活を規定されてしまら面が少ないことや， ある種の達観的心境を得やすい状態にあること が，無理のない療養がでさることに影響してい ると考觉られる。

また, タイプIIは糖尿病, タイプIIIは肝臓病 の割合が高かった. 糖尿病は, 病気のコントロー ルといら面で患者の自己管理が影響する度合い が高く，それも毎日毎食の食事の管理が必要で， またそれは血糖といら指標にすぐに反映され， 評価される. 一方, 肝臓病は自己管理の病気の コントロールへの影響が明確ではなく, ダ、イレ クトに自己管理の良い悪しを表す指標もない。 このことが困難感の相違となってタイプ II と III の違いに現れたと考えられる。

プラス面やモットーについての表現から相違 をみてみると，タイプIIでは自分の人生を自分
で満足するように切り開いていこら・いけると いう, Locus of Controlでいう内的統制がみら れる一方, タイプIIIでは，生かされているとい ら感覚や神仏の加護などに表現されているよう に外的統制がみられる。また，タイプIIは仕事 や趣味の達成など，外に関心が向いている一方， タイプIIIは自分の心身の状態を基調にして考兄 るなど，自分という内面に関心が向いているこ とが多いようである。

その他のタイプに属する患者は少数であった が，それぞれに特徴のあるものだった。

タイプ I は完全主義型と命名したように，患 者の完全主義的な性格が療養のやり方に大きく 影響しているように思われる，自分で厳しく自 己管理していることを自ら表現し，タイプIIに ある「つい○○してしまら」といらよらな気持 ちの甘さやゆとりを表す表現はない。それだけ に常に神経を張り詰めて療養生活を送っている 様子が伺えるタイプである. 病気のコントロー ルは不良の者がいなかったように, 厳しく行っ ている分，コントロール状態は良好に保たれる 割合が高いであろらが，常に気を抜かないで毎 日の療養生活を送り続けることはストレスフル なものと思われる。精神的な休息を入れていか なければ, 当然疲労も考兄られ, また, コント ロールが不良に傾いた場合の「これ以上やるす べがない」という苦しさや挫折感は大きいと考 えられる。

タイプ VWは療養上の自己管理面で守れない部 分を多く表現しているが，決して守っていない わけではなく，守らなければいけないといら意 識が強く, 実際に守っている部分もあるのだが, 守れない部分の方が強く意識されているように 思われる，そこには自信の言失による自己価值 低下の感情や不安の増大が影響していると考兄 られ，七ルフケア達成感も低いと考えられる.

タイプ Vは家族に全面的に自分の療養を依存 しているものであるが, 年齢が高く, 人の世話 をうける割合が高く，強力に世話をしてくれる 家族がいる場合に生じると考えられる。

タイプ Vはは慢性病に対する療養に専念でさな い状況をもたらす重荷が存在しており，自分の 療養について落ち着いて取り組めず，そのため 
に不安や不満足感を味わっていると考えられる.

タイプVIIは療養の必要性は分っているが実行 しないタイプで，これには病識の欠如や開き直 りの感覚が存在していると考㝋られる.

このように，タイプ I， $\mathrm{V} 〜 \mathrm{VI} は$ 少数ではあ るが確かに臨床で経験できるタイプであり，こ れらの人は大多数であるタイプIIやIIIの人達へ の援助の方法とは別の方法を考える必要がある ことが示唆される患者群である。

\section{2. 療養上の困難感をもたらす要因}

困難感を強く感じるタイプとしては, タイプ I , II， IV，VIが，あまり感じないタイプとし ては，タイプIII， IVがあげられる．療養上の困 難感は療養を継続していく上で障害となるため, この障害の性質を明らかにし，それを患者と共 に解決していくプロセスが慢性病患者看護にとっ て重要となると考えられる.

困難感有無の理由から考兵方, 困難感に影 響する要因として, 慣れ ((f)), 遵守感 $((b)$, $(\mathrm{m}))$ ，他の価值との競合 $((\mathrm{d}),(\mathrm{i}),(\mathrm{j}))$ ，必 要とされる自己管理の内容と程度 (疾患による 違い, 病状の軽重による違い) $((\mathrm{a}),(\mathrm{h}))$, 周 囲の理解・協力 $((\mathrm{e}),(\mathrm{j}))$, 達観的心境 $((\mathrm{g}))$ が考えられた。また，困難感に伴ら感情につい て，その理由の内容からみてみると，(h)では 苦痛を, (i)〜 (1) では苦労や負担感を, (n)で は負担感や苦痛を感じていると考えられる。こ のような苦痛・苦労・負担感は, 患者が慢性病 の療養を継続していく過程である程度必然的に 味わう感情である.しかしこのような感情が増 強した場合, 患者の療養の継続が困難となるの は当然と考えられ，そればかりか，患者の自己 概念をも脅かす結果になりかねない。このこと を考慮すると, 慢性病患者の療養に伴ら苦痛・ 苦労・負担感を軽減する援助が，慢性病患者の 看護にとって重要な課題となるのは明らかであ る.

療養上の困難感の無い理由の中で，（a）制限 が少ないために自由に生活できているや(b) 遵 守しなければといら意識が少ないといら理由と， （f）療養行動が習慣化しているや $(\mathrm{g})$ 達観して いるといら理由では, 療養に対しての姿勢は大
きく異なると考えられる.すなわち, 前者は療 養に主体的に取り組んでいるとは言えないが， 後者は主体的に取り組んだ結果現在の困難のな い状況が作り出されているといえる.このよう にタイプIIIの中でも療養の取り組み姿勢が異なっ ていると考えられる.

\section{3．療養のタイプを考慮した看護のあり方}

本結果を考慮した慢性病患者の療養を支える 看護のあり方について考皇てみたい，援助に当 たっては，末ず療養のタイプを判断する必要が あるが，本調査でも示されたようにタイプII IIIが大多数であり，一般的なもの之考えられる. その他のタイプの患者はそれぞれ特徵的な表現 があり，それらの表現に気をつけていればすぐ に判別できるものと考光る。すなわち，タイプ I は完全主義的な表現が多いこと，VWできな い部分を自責的に表現することが多いこと，V は患者の言動の決定権を持っているような家族 の存在があること, VIは療養以外の不安や心配 について多く語ること, VII は医療者の注意に素 直に耳を傾けようとせず，開き直ったような言 動がみられるものである.よって，タイプII III 対する援助を基本に拈き，その他のタイプ が判断される場合にそのタイプの特徴に合わせ た援助を行ら必要がある。

療養の各タイプの特徵から示唆される看護の 課題を表 4 に示した. タイプII とIIIに関する援 助方法は, 既存の文献で種々述べられているよ らに，我々が一般的に行っている患者の自己管 理を推進させ, 療養上の安寧を高めるための援 助である. その際，II とIIIの違いを考慮して援 助にあたることが望まれる、すなわち，タイプ II は，療養上少なからず困難感を抱いている人 なので，その困難感から生じている苦痛や苦労， および負担感を軽減するべく援助を行ら必要が あろら、その際, 自分なりの生さ方, モット一 を大事にしている人のため, その生き方を尊重 し, 療養生活とその人の日常生活, 社会生活と の競合をできるだけ少なくさせるような療養の やり方を工夫できるような援助が必要であろら。

一方タイプIIIは, 無理なく自然に療養を行っ ている人である。しかし困難感のない理由でみ 
表 4 療養のタイプ別看護の課題

\begin{tabular}{|c|c|c|c|c|}
\hline \multicolumn{2}{|r|}{ 療養のタイプの特徵 } & \multicolumn{2}{|r|}{ タイプの命名 } & 護の \\
\hline \multirow{4}{*}{$\begin{array}{l}\text { 自 } \\
\text { 分 } \\
\text { で } \\
\text { 取 } \\
\text { り } \\
\text { 組 } \\
\text { 导 } \\
\text { 療 } \\
\text { 養 } \\
\text { 生 }\end{array}$} & 㛜しく細かく行ら療養 & I & 完全主義型 & $\begin{array}{l}\text { 療養上のストレスの緩和 } \\
\text { 疾コントロール不良時の挫折感の予防 }\end{array}$ \\
\hline & $\begin{array}{l}\text { 苦労はあるが，自分なり } \\
\text { に工夫した療養 }\end{array}$ & II & 現実型 & $\begin{array}{l}\text { 苦痛・苦労・負担の理解 } \\
\text { 療養のやり方の工夫への助言 }\end{array}$ \\
\hline & $\begin{array}{l}\text { 苦労はあ屯り感じず無理 } \\
\text { のない療湌 }\end{array}$ & III & 自然態型 & 療養姿勢の確認と尊重 \\
\hline & 守れない部分の多い療養 & IV & 自己価値低下型 & $\begin{array}{l}\text { 自己価値低下の感情を助長させない配慮さ踏める援助 } \\
\text { 自信を取り戻すプロセスを踏 }\end{array}$ \\
\hline \multicolumn{2}{|c|}{ 妻任せの療養生活 } & V & 依存型 & 妻(重要他者)との役割関係の把握 \\
\hline \multicolumn{2}{|c|}{ 専念できない療養生活 } & VI & 重荷型 & 不安の軽減による情緒的安定の確保 \\
\hline \multicolumn{2}{|c|}{ 療養を軽視した生活 } & VII & 反抗型 & 医療者との安定し信頼しあえる関係作り \\
\hline
\end{tabular}

たように，その中でも療養姿勢が主体的な人と 消極的な人が拈り，それを見極めたら兄で援助 を考光る必要がある。無理のない自然態を望ん でいる人にストレスとなるよらな療養のやり方 を強要すると，それを回避してしまら恐れがあ る.よって，消極的な姿勢の人には，ストレス の少ない療養のやり方を共に考光, 生活に溶け 込むように導入できるよう援助していく必要が あろら。

タイプ I , $\mathrm{I} \sim \mathrm{VII}$ は特別な配慮を要する.タ イプIは自分に厳しく療養を課している人であ るが，篇しく行っている分それによるストレス も多く感じているであろらから，その療養の努 力を支持し，ストレスを緩和できるアドバイス を与える必要があろう。また，病気のコントロー ルが不良に傾いた際の挫折感が強いことを考慮

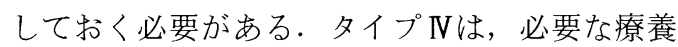
が行えない，守れないといら意識が強いため， その自己価值低下の感情を助長させないよう注 意し，自信を取り戻すプロセスを踏めるよう， できる部分を見つけ，できた事を評価していく 必要があろう。野口 ${ }^{9}$ はこのタイプに属する患 者の看護プロセスについて詳細に述べている. タイプ Vは，妻任せであるため，妻がかかわれ ない部分に拈けるその人の療養のやり方に目を 向け，その部分での自主性を育てる必要があろ ら.タイプVIは，心理的に不安定な状態である ため，亦ずその不安の内容に耳を傾けるなどし て心理的安定をはかることが必要である。その 安定が得られた後, その人の環境の中で可能な
療養のやり方を少しずつ組み入れていけるよう なアドバイスが必要であろら。タイプVIIは少な くとも開き直りの感情を助長させないために, 患者の療養のやり方の非難は避けるべきであろ う。まずは我々医療者との安定し信頼し合える 関係作りに焦点を括き，その後に療養のやり方 を共に考えていく姿勢を示し続けることであろ 丂.

\section{4. 研究の限界と今後の課題}

予備調査で得られた療養のタイプを基に本調 査の分析に当たった結果, 本調査の対象数は予 備調査の約 7 倍であるにもかかわらず, 本調査 で新たに分類できたタイプは一つのみであった。 その理由として以下の 2 点が考えられた.

一点目は対象群の相似で, 都内・都下に在住 で, 面接調査に応諾した患者という点である。 二点目は分析資料の相違で, 予備調査では面接 の録音テープの逐語記録を資料としたが，本調 査では面接者の面接記録を資料とした点である. 面接記録は面接者のコメント欄を設けて記録の 充実を図ったが，その記録内容は面接者の取捨 選択を通して得られたものである．その点が予 備調査で得られたタイプ以外のタイプを見出せ なかったことに影響しているのかもしれない。

また本結果はタイプを横断的に捉えて分類し たが，これらの療養のタイプは決して固定的な ものではないと考兄られる. 時間的な経過や環 境の変化に伴らタイプの変化を今後の課題とし て，明らかにしていきたい。 


\section{〔おわりに〕}

本研究は, 患者の療養生活に関する自由な表 現から，慢性病患者の様々な療養のあり様を， 看護者側の評価といら観点を踏をえて捉えた. その結果, 患者の療養のやり方の特徵に応じた 看護の課題が明らかになった. 今後この結果を 看護実践に活用し，慢性病患者の療養指導を行 ら上で, 患者の療養のやり方の特徵を把握して 援助していくことの意義を明らかにしていきた い.

\section{[参考文献]}

1 ) 中西睦子, 他：慢性病患者のセルフケアの構 造と看護の役割に関する予備調査報告, 第 5 回保健医療行動科学会大会抄録 : 22,1990

2 ) 平野かよ子, 他：セルフケア意識のスケール の開発と測定結果について, 第 5 回保健医療 行動科学会大会抄録：23,1990

3 ) 雨宮悦子, 他：患者一医療者関係スケールの
開発と測定結果について, 第 5 回保健医療行 動科学会大会抄録：26,1990

4 ）正木治恵, 他 : 慢性病患者のセルフケア構造 に関する面接調査, 日看科会誌, 10(3): 72-73, 1990

5 ) 井部俊子, 他：セルフケア達成感スケールの 開発抢よび信頼性, 妥当性の検討, 日看科会 誌, 10(3)：74-75, 1990

6 ) 小野ツル子, 他：慢性病患者の民間療法資源 の利用状況, 第 6 回保健医療行動科学会大会 抄録：27, 1991

7 ) 石原逸子, 他：慢性病患者のセルフケアの構 造と看護の役割に関する研究, 第 2 回保健医 療行動科学国際会議 : 45-46,1991

8 ) アンセルムL.ストラウス, 他: 南裕子監訳 : 慢性疾患を生さる ケアとクォリティ・ライ フの接点, 医学書院, 第 1 版, 1987

9 ) 野口美和子：セルフケアの推進と看護婦の役 割，看護技術，29(6)：754-761, 1983 